УДК 37.013+378:398.1

UDC 37.013+378:398.1

DOI: $10.31475 /$ ped.dys.2018.25.02

АНДРІЙ БАЛЕНДР,

кандидат педагогічних наук, доцент

(Украӥна, Хлельницький, Національна акаделія

Державної прикордонної служби Украӥни ілені Богдана Хлельницького,

вул. Шевченка, 46)

ANDRII BALENDR,

candidate of pedagogical sciences, associate professor

(Ukraine, Khmelnytskyi, National Academy of the State

Border Guard Service of Ukraine named after Bohdan Khmelnytskyi,

Shevchenko str., 46)

ORCID: 0000-0003-4610-2830

\title{
Уніфікована програма базового рівня для підготовки фахівців з охорони кордону країн Свропейського Союзу
}

\section{Common Core Curriculum for Border Guards Basic Training in the European Union Countries}

У статті автором охарактеризована уніфбікована програла базового рівня для підготовки фбахівців з охорони кордону крайн Європейського Союзу (далі - УПП). Украйнське прикордонне відомство активно впроваджує УПП в систему підготовки украйнських ббахівиів з охорони кордону в своїх відомчих закладах освіти. УПП для підготовки прикордонників складається із Загального розділу і модулів: "Повітряний кордон», "Сухопутний кордон» $i$ «Морський кордон». Ця програла підготовки сприяе взаємодії між співробітниками прикордонних служб країн $Є С$ пропонуючи уніфбікований стандарт базової підготовки, що повинно допомогти прикордонникам усіх краӥн ЄС $i$ країн, з якими підписані робочі домовленості, виконувати свої фбункиї на високому пробьесійнолу рівні, з повагою та шанобливим ставленням до людської гідності. Автором було проведено аналіз можливості використання ивого досвіду з метою його впровадження в систему профбесійної підготовки персоналу прикордонного відомства Украӥни.

Ключові слова: уніфбікована підготовка, фбахівиі з охорони кордону, рівні кваліфбікацій, країни Європейського Союзу.

The article reveals characteristics, the process of development and advantages of using of a Common Core Curriculum for the basic training of border guards (CCC) of the European Union countries. The Ukrainian Border Guard Service is also actively implementing this training program in its departmental educational and training institutions. The CCC consists of the General Chapter and modules "Air Border", "Land Border" and "Sea Border". The updated version of the 2018 CCC is aligned with the 4th and 5th levels of the Sectoral Qualifications Framework for border guarding and corresponds with the principles of the 4th and 5th levels European Qualifications Framework for Lifelong Learning. This training program facilitates interaction between the staff of the border services of the EU countries, offering a unified standard for basic training. This should help border guards perform their functions on a high professional level with respect for human dignity. The author analyzed the possibility of using this experience in order to implement it in the system of professional training of the personnel of the border guard agency of Ukraine. This should facilitate mobility and development of exchange programmes for the officers of border guard organizations, with the goal of providing common $E U$ approaches to the organization of border security and introduction of common border guard standards across the EU. The CCC for border guards has also been considered regarding the possibility to utilize the experience of the leading EU border guard organisations in order to introduce it into the training system of the State Border Guard Service of Ukraine. The author indicates that the system of training of the personnel of the State Border Guard Service of Ukraine requires such an instrument for development of national border guard curricular for both educational and training purposes, and that presupposes further study of the border guard's training system of the EU countries.

Key words: common training, border guards, qualification levels, European Union countries.

Вступ / Introduction. Сьогодні, розробка та впровадження спільних освітніх програм вважаеться одним з пріоритетних напрямків розвитку професійної освіти фахівців, міжвузівського співробітництва різних країн світу, особливо між країнами Свропейського Союзу (ЄС). Аналогічно 
й в системі професійної освіти й підготовки персоналу прикордонних відомств країн ЄС вже протягом тривалого часу відбуваються процеси інтеграції Уніфікованої програми базового рівня для підготовки фахівців з охорони кордону (Common Core Curriculum, 2017). Державна прикордонна служба України (ДПСУ), у зв'язку з обраним керівництвом держави європейським вектором розвитку, також приедналась до цього проекту.

З огляду на це, актуальним вбачаеться вивчення досвіду розробки та імплементації в країнах ЄC Уніфікованої програми базового рівня для підготовки фрахівців з охорони кордону базового рівня (УПП) для її впровадження у відомчих закладах освіти ДПСУ.

Мета та завдання / Aim and Tasks. Метою дослідження е висвітлення особливостей УПП базового рівня для підготовки фахівців з охорони кордону країн $Є С$ для подальшого впровадження передового досвіду в систему професійної підготовки персоналу ДПСУ.

Методи / Methods. 3 метою досягнення поставленої мети дослідження було застосовано такі методи: теоретико-критичний, логічний аналіз педагогічної та психологічної, методичної літератури, нормативно-правової документації - з метою визначення сучасний стану уніфікованої підготовки прикордонників у країнах $\mathrm{CC}$; синтез, порівняння, класифікація - для уточнення та обюрунтування проблеми створення уніфікованих програм підготовки, обтрунтування та формулювання перспективних напрямів розвитку УПП для підготовки персоналу прикордонних відомств країн ЄС; емпіричний - педагогічне спостереження, збір та узагальнення самостійних характеристик, аналіз УПП, навчально-методичного забезпечення, освітніх технологій, що використовуються в різних закладах освіти прикордонних відомств країн $\mathrm{CC}$.

Результати / Results. Сьогодні, в країнах ЄС завдяки Шенгенському законодавству досягнута гармонізація нормативно-правової бази, що регламентуе виконання завдань усіх прикордонних служб, тому потрібно також забезпечити гармонізацію базової підготовки. Відношення до громадянина повинно бути однаковим на всіх ділянках зовнішніх кордонів $\mathrm{CC}$ : на сухопутних кордонах, в морських портах та аеропортах (Common Core Curriculum, 2017).

Українське прикордонне відомство також активно запроваджуе УПП в своїх відомчих закладах освіти й підготовки: Нащіональній академії Державної прикордонної служби України, Головному центрі підготовки персоналу ДПСУ, Кінологічному навчальному центрі, Навчальнотренувальному загоні морської охорони.

Автор, як представник ДПСУ, у 2012 р. був призначеним національним експертом з питань впровадження УПП, е співавтором даної програми, брав участь в роботі з ії оновлення та іï узгодження 3 Галузевою рамкою кваліфікацій сфери охорони кордону (ГРК), в пленарних засіданнях і роботі в складі робочих груп. УПП базового рівня відповідае ГРК 4 і 5 рівнів (Sectoral Qualifications Framework, 2012). Загалом, після успішного завершення базового навчання за УПП (Загальний розділ та один або декілька практичних модулів - «Повітряний кордон», «Сухопутний кордон» $\mathrm{i}$ «Морський кордон»), в день закінчення навчання співробітники прикордонного відомства відповідно до програми підготовки повинні мати сформованими професійні компетентності визначені у ГРК, і які необхідні їм для виконання службових обов'язків з охорони кордону.

Хоча УПП е всеосяжною програмою, яка містить результати навчання з усіх сфер діяльності 3 охорони кордону, необхідною умовою розвитку професійних компетентностей для роботи на другій лінії контролю є досвід роботи. Щоб бути компетентним у проведенні широкого спектру завдань щодо перевірок на другій лінії контролю співробітники прикордонних служб, як правило, повинні пройти спеціалізоване навчання або підвищити свою кваліфікацію в певних галузях охорони кордону або на курсах керівного складу. Такі компетентності виходять за рамки УПП, хоча ця програма підготовки є відправною точкою для їх розвитку.

Обговорення / Discussion. Дослідженнями професійної підготовки фрахівців з охорони кордонів зарубіжних країн займались Н. Ринденко, Т. Тронь та ін. Практичні аспекти підготовки курсантів Національної академії Державної прикордонної служби України імені Богдана Хмельницького досліджував I. Блощинський (Блощинський, 2016; 2017). Проте, наші розвідки засвідчили, що наразі грунтовного аналізу уніфрікованих програм для підготовки фахівців 3 охорони кордону країн $\mathrm{CC}$ практично не існуе.

Необхідність запроваджувати і розвивати спільні програми підготовки для прикордонників на європейському рівні вказана у Регламенті про Європейську прикордонну та берегову охорону, де серед іншого, також наголошуеться на забезпеченні навчання інструкторів для прикордонних відомств країн ЄC з питань пов'язаних з охороною кордону, фуундаментальних прав людини, міжнародного захисту, морського права і т.і. Основне завдання таких спільних програм підготовки - просувати кращі прикордонні практики і стандарти з питань реалізащії нормативно-правової бази у галузі управління кордонами СC (Regulation EU 2016/1624, 2016).

Подібні спільні з країнами ЄС освітні програми діють в інших галузях в нашій державі. Наприклад, у Полтавському університеті економіки і торгівлі функціонує Міжнародна інноваційна 
освітня онлайн-програма підготовки магістрів із підприемництва розроблена консорціумом п'яти закладів вищої освіти ЄC: Advenio eAcademy (Мальта), Університет Яніни (Греція), Університет Сент-Іштвана (Угорщина), Університет Барі Альдо Моро (Італія), Університет Жиліна (Словаччина) та Полтавський університет економіки і торгівлі в Україні (Освітня програма підготовки магістрів, 2018).

Приймаючи рішення про інтеграцію спільної програми підготовки у систему підготовки національних фахівців з охорони кордону, країни ЄC вирішили, що така підготовка має відбуватись на основі спільних програм підготовки розроблених Агенцією FRONTEX (Європейська організація прикордонної та берегової охорони). Ці програми підготовки є уніфікованими стандартами для закладів освіти з підготовки прикордонників та берегової охорони у всіх країнах ЄС. Після впровадження УПП у національні програми підготовки процес навчання має спрямовуватися таким чином, щоб студенти одержували знання у своїй професійній області, необхідні навички й формували відповідне ставлення, які будуть їм потрібні для виконання професійних обов'язків з охорони кордону. Проте, на національному рівні завжди заохочуеться більш поглиблена підготовка персоналу ніж передбачено в УПП.

Оновлена УПП базового рівня для підготовки прикордонників складається із Загального розділу і модулів «Повітряний кордон», «Сухопутний кордон» і «Морський кордон». Перш ніж перейти до вивчення окремих модулів необхідно обов'язково завершити вивчення Загального розділу. Кожен з них розбито на категорії, розділи та теми. Кожна тема включае власні результати навчання, як сукупність знань, навичок та компетентностей, а також опис методології оцінки $\mathrm{i}$ рекомендовані методи підготовки. Для викладачів до деяких 3 предметів було включено рекомендований приблизний зміст. Загальний розділ містить три модулі, а саме: «Загальна прикордонна підготовка»; «Загальна правоохоронна підготовка за прикордонними стандартами»; «Практичні вміння прикордонників». Кожний з модулів «Сухопутний кордон», «Повітряний кордон» і «Морський кордон» містить два підрозділи, а саме: спеціальне законодавство та спеціальну практику (Common Core Curriculum, 2017).

Основна ідея УПП полягає в тому, що всі прикордонники та фахівці берегової охорони повинні вивчати Загальний розділ відповідно до національного законодавства і потреб. Залежно від потреб прикордонної служби, вони також можуть вивчати один або кілька інших модулів. Наприклад, якщо очікуеться, що прикордонники будуть працювати на сухопутній ділянці кордону і в аеропортах, вони повинні пройти модулі «Сухопутний кордон» і «Повітряний кордон» на додаток до Загального розділу.

Філософія УПП щодо підготовки до здійснення прикордонного контролю другої лінії пояснюеться у вступі до загальної правоохоронної підготовки за прикордонними стандартами. Під час базової підготовки прикордонників розвиваються перш за все компетентності, які дозволяють брати на себе відповідальність за проведення ефективної перевірки осіб на першій лінії контролю та виконання (під наглядом) щоденних, простих завдань щодо здійснення перевірок на другій лінії контролю.

3 точки зору берегової охорони, УПП повністю відповідае функціям берегової охорони описаним у Регламенті про Свропейську прикордонну та берегову охорону. УПП не намагається описати навігаційні компетенціі в деталях, а скоріше фоккусуеться на основних функціях прикордонників та берегової охорони. Специфічні професійні знання, навички та компетентності, наприклад, такі як експлуатація судна і навігація, описується в інших спеціалізованих документах на національному або міжнародному рівні.

Регламентом ЄC 2016/1624 про Агенщію Свропейської прикордонної та берегової охорони передбачено проведення спільних операцій. Співробітники прикордонних служб, які за необхідності беруть участь у спільних операціях на зовнішніх кордонах, повинні мати можливість працювати разом безпечно і ефективно. Хоча прикордонники, які беруть участь у спільних операціях отримують спеціалізоване навчання, високого рівня оперативної взаємодії можна досягнути лише шляхом узгодженої базової підготовки (Regulation EU 2016/1624, 2016).

Здатність працювати разом називається взаємодією або функціональною інтероперабельністю. У традиційному значенні це означае, що прикордонники мають бути в змозі працювати пліч-о-пліч під час проведення спільних операщій. У більш широкому значенні це означае, що всі прикордонники працюють разом, навіть коли вони виконують власні задачі на своїх робочих місцях. Це пояснюеться тим, що усі дії, які вони виконують, мають бути единими та зрозумілими іншим колегам по всій Європі. Оновлена УПП сприяе такій взаємодії пропонуючи уніфрікований стандарт базової підготовки співробітників прикордонних служб країн ЄС. Це повинно допомогти прикордонникам виконувати свої функції на високому професійному рівні, 3 повагою та шанобливим ставленням до людської гідності (Interoperability Assessment Program, 2015). 
Нормативною базою, яка лягла в основу УПП є декілька документів $\mathrm{CC}$, найважливішими 3 яких е Шенгенський кодекс про кордони (Schengen Border Code, 2016) та Регламент про Європейську прикордонну та берегову охорону (Regulation EU 2016/1624, 2016). УПП належить до навчального портфоліо FRONTEX і їі було розроблено, оновлено та впроваджено у тісній співпраці з країнами СC та країнами, які підписали робочі домовленості з FRONTEX.

Базова УПП для прикордонників та фахівців берегової охорони ЄС була розроблена в 2003 р. i з того моменту регулярно оновлюеться. Вона реалізована в усіх країнах $\mathrm{CC}$ та в декількох країнах робочих домовленостей FRONTEX. Оновлення 2017 р. спрямоване на узгодження УПП з ГРК, а також на оновлення змісту. Зокрема, акцент було зроблено на питаннях, що відносяться до основоположних прав людини та нових викликів у галузі безпеки і управління кордонами всередині та за межами Свропи, що вимагае від фахівців 3 охорони кордонів нових компетентностей (Балендр, 2017).

Підготовка до практичного впровадження УПП, що передбачало постановку освітніх завдань у вигляді оперативних цілей, досягнення яких можливо було б оцінити, було завершено й схвалено всіма країнами СC, а також Норвегією й Ісландією 15 червня 2004 р. Офіційно процес впровадження УПП на національному рівні розпочався 15 червня 2004 року.

Наприкінці 2005 р. було розпочато процес оновлення УПП під загальним керівництвом Агенції FRONTEX. 3 початку 2006 р. ця робота велася як незалежний проект FRONTEX. Двадцять п'ять представників з 18 країн $\mathrm{C} \mathrm{увійшли} \mathrm{до} \mathrm{складу} \mathrm{робочих} \mathrm{груп.} \mathrm{Крім} \mathrm{того,} \mathrm{до} \mathrm{роботи} \mathrm{в} \mathrm{якості}$ експертів залучалися представники Міжнародної організації з міграції (МОМ), Управління Верховного Комісара ООН з питань біженщів (УВКБ ООН), Свропейський комітет з недопущення тортур та Європейської навчальної програми у сфері надання притулку з метою отримання консультацій у сфері основоположних прав людини. Процес внесення змін до УПП аналізувався трьома вишами: Інститутом досліджень у галузі освіти (Фінляндія); Університетом національної оборони ім. Міклоша Зріни (Угорщина) та Болонським Університетом (Італія). Наприкінці 2007 р. оновлений варіант УПП було подано на розгляд Дирекції FRONTEX та Європейській Комісії. Церемонія схвалення оновленої версії УПП відбулася 4-го березня 2008 в Італії (Common Core Curriculum, 2017).

Згідно з проектом «Активної імплементації УПП» у 2008 р. уніфіковану програму було перекладено на мови европейських країн та впроваджено у національні програми підготовки прикордонників. Після ï використання протягом певного часу, у 2009 р. результати реалізації УПП було оцінено «Програмою оцінювання інтероперабельності» (ПОI) з метою визначити повноту імплементації УПП та рівень інтероперабельності прикордонників, які закінчили навчання за цією програмою. Результати перевірки виявились позитивними (Interoperability Assessment Program, 2015).

Життевий цикл УПП відбуваеться за наступною схемою: використання - оцінювання внесення змін - імплементація. У 2010 р. після оцінки отриманих результатів стало зрозуміло, що знадобиться проведення ще одного етапу оновлення УПП. Цього разу воно мало за мету розгляд питань посилення взаємодії, вивчення нового законодавства та технічного розвитку у сфері охорони кордонів $\mathrm{CC}$ а також підсилення значення основоположних прав людини. Відповідно до життевого циклу розвитку УПП, Агенція FRONTEX прийняла рішення запустити трете оновлення програми на початку 2016 р. На цей раз оновлення змісту відбувалося паралельно з узгодженням УПП з ГРК. Оновлений варіант УПП 2017 р. було узгоджено з ГРК 4-го та 5-го рівнів, відповідає принципами Європейської рамки кваліфікацій для навчання впродовж життя (СРК) 4-го та 5-го рівнів. Для процесу оновлення четвертого видання УПП були запрошені експерти-представники країн $\mathrm{CC}$, країн, з якими підписані робочі домовленості, фахівці оперативного відділу FRONTEX, MOM, УВКБ ООН, а також Консультативного центру FRONTEX з питань основоположних прав людини.

Висновки / Conclusions. Стратегія розвитку системи професійної підготовки персоналу ДПСУ відповідно до вимог Болонського та Копенгагенського процесів надае змогу відомчим навчальним закладам максимально реалізувати свій потенщіал у плані відповідності вимогам европейської системи знань та адаптувати систему підготовки українських прикордонників до принципів, норм, стандартів і основних положень прийнятних i ефективних для нашого прикордонного відомства. Реформування системи силових та правоохоронних відомств України, зокрема й ДПСУ, потребують розробки і застосування нових підходів, технологій та методів професійної підготовки сучасних прикордонників, зокрема впровадження УПП. У зв'язку з цим, охарактеризовано процес створення і впровадження на національному рівні УПП для підготовки прикордонників країн $\mathrm{CC,} \mathrm{висвітлено} \mathrm{зв'язок} \mathrm{даної} \mathrm{програми} \mathrm{з} \mathrm{ГРК} \mathrm{та} \mathrm{ЄРК.}$

Перспективами подальших наукових розвідок вважаємо дослідження та узагальнення досвіду розробки та впровадження Спільної магістерської програми підготовки прикордонників країн ЄС в 
галузі стратегічного управління кордонами, з метою ї подальшого впровадження в систему підготовки персоналу ДПСУ.

\section{Список використаних джерел і літератури / References:}

1. Common Core Curriculum for Border Guard Basic training in the European Union (CCC 2017). (2017). Warsaw, Poland: Rondo ONZ 1. [in English].

2. Sectoral Qualifications Framework for Border Guarding (Vol. 2). (2013). Warsaw, Poland: Rondo ONZ 1. [in English].

3. Блощинський, I. (2016). Структурно-функціональна модель підготовки майбутніх офріцерівприкордонників на основі технологій дистанційного навчання. Педагогічний дискурс, 20, 15-20. / Bloshchynskyi, I. (2016). Strukturno-funktsionalna model pidhotovky maibutnikh ofitseriv-prykordonnykiv na osnovi tekhnolohii dystantsiinoho navchannia [Structural and Functional Model of Future Borderguard Officers' Training on the Basis of Distance Learning Technologies]. Pedahohichnyi dyskurs, 20, 15-20. [in Ukrainian].

4. Bloshchynskyi, I. H. (2017). Enhancement of cadets' practical training at the National Academy of the State Border Guard Service of Ukraine named after Bohdan Khmelnytskyi. Science and Education, 4, 5-10. [in English].

5.Regulation (EU) 2016/1624 of the European Parliament and of the Council of 14 September 2016 on the European Border and Coast Guard. Retrieved from https://publications.europa.eu/en/publication-detail//publication/65db3442-7bcf-11e6-b076-01aa75ed71a1/language-en (last accessed 26.07.2018). [in English].

6. Освітня програма підготовки магістрів із підприемництва / Osvitnya prohrama pidhotovky mahistriv iz pidpryyemnytstva [Educational Masters Degree Program in Entrepreneurship]. Retrieved from http://puet.edu.ua/uk/osvitnya-programa-pidgotovki-magistriv-iz-pidpriiemnictva_(last accessed 26.07.2018). [in Ukrainian].

7. Interoperability Assessment Program Study. (2015). Warsaw, Poland: European Agency for the Management of Operational Cooperation at the External Borders of the Member States of the European Union. [in English].

8. Schengen Border Code. Retrieved from https://eur-lex.europa.eu/legalcontent/EN/TXT/?uri=CELEX:32016R0399 (last accessed 26.07.2018). [in English].

9. Балендр, А. (2017). Характеристика рівнів галузевої рамки кваліфрікацій для підготовки прикордонників країн Свропейського Союзу в академічній освіті. Педагогічний дискурс, 22, 9-14. / Balendr, A. Kharakterystyka haluzevykh rivniv kvalifikatsiynykh vymoh dlya pidhotovky prykordonnykh sluzhb derzhavchleniv ES v akademichniy osviti [Characteristics of the Sectoral Qualifications Framework Levels for the EU Member States Border Guards Training in Academic Education]. Pedahohichnyi dyskurs, 22, 9-14. Retrieved from http://ojs.kgpa.km.ua/index.php/peddiscourse/article/view/9_(last accessed 26.07.2018). [in Ukrainian].

Дата надходження статті: «09» серпня 2018 р.

Стаття прийнята до друку: «15» жовтня 2018 р.

Балендр Андрій - доцент кафедри англійської мови Національної академії Державної прикордонної служби України імені Богдана Хмельницького, кандидат педагогічних наук, доцент

Balendr Andrii - assistant professor of the English language department of National Academy of the State Border Guard Service of Ukraine named after Bohdan Khmelnytskyi, candidate of pedagogical sciences, associate professor

\section{Цитуйте ию статтю як:}

Балендр, А. (2018). Уніфікована програма базового рівня для підготовки фрахівців з охорони кордону країн Свропейського Союзу. Педагогічний дискурс, $25,17-21$.

\section{Cite this article as:}

Balendr, A. (2018). Common Core Curriculum for Border Guards Basic Training in the European Union Countries. Pedagogical Discourse, 25, 17-21. 